\title{
SURPRISE EFFECT OF EURO AREA MACROECONOMIC ANNOUNCEMENTS ON CIVETS STOCK MARKETS
}

\author{
Laura Wallenius, Elena Fedorova, Sheraz Ahmed, Mikael Collan*
}

\begin{abstract}
The macroeconomic announcements and their effects on stock markets are considered to be a measure of stock market integration. Earlier studies show that integrated stock markets exhibit immediate reaction to international macroeconomic news, whereas partially integrated or segmented markets mostly do not react to such announcements. This paper investigates the effect of surprises disguised in the macroeconomic announcements made by the European Monetary Union on CIVETS (Colombia, Indonesia, Vietnam, Egypt, Turkey, and South Africa) stock markets. Daily stock market data starting from January 1, 2007 to December 31, 2012 is analysed. The impact of macroeconomic announcements is estimated by using EGARCH model. The results show that the returns of four out of six CIVETS stock markets significantly react on the day of macroeconomic announcements, whereas the market volatility of all markets is affected due to the EMU's announcements. The results also show that not all types of announcements have significant impact on returns and volatilities in CIVETS, highlighting the importance of the contents of macroeconomic surprises.
\end{abstract}

Keywords: macroeconomic announcements, integration, spillovers, emerging markets, CIVETS JEL Classification: C32, F36, G12, G15

\section{Introduction}

CIVETS (Colombia, Indonesia, Vietnam, Egypt, Turkey, and South Africa) is a fairly new acronym coined in 2009 by Robert Ward, Global Director of the Global Forecasting Team of the Economist Intelligence Unit to refer to six dynamic frontier markets that are considered new rising economies. This grouping principals are similar to that of the well-known BRIC, "Asian Tigers", and BRICS. The CIVETS, as well as other frontier economies have caught the interest of the international investment community because of possible higher returns that may escape the well-known negative spillovers from one developed market to another.

In the recent years, CIVETS have opened their markets to foreign investments and international trade, becoming more susceptible to external shocks. This makes the CIVETS countries to be interesting for studies of spillover effects and integration. It can be expected that the exposure to external shocks from global markets has increased in the wake of internationalization, especially from European countries, as the EU is the largest or one of the largest trading partner for CIVETS.

* Laura Wallenius, School of Business and Management, Lappeenranta University

of Technology, Lappeenranta, Finland (laura.wallenius@lut.fi);

Elena Fedorova, School of Business and Management, Lappeenranta University

of Technology, Lappeenranta, Finland (elena.fedorova@lut.fi);

Sheraz Ahmed, School of Business and Management, Lappeenranta University of Technology, Lappeenranta, Finland (sheraz.ahmed@lut.fi);

Mikael Collan, School of Business and Management, Lappeenranta University of Technology, Lappeenranta, Finland (mikael.collan@lut.fi). 
To be more precise, the EU is the largest trading partner of three CIVETS countries (Egypt, Turkey, and South Africa) while the EU is the $2^{\text {nd }}$ largest trading partner of Colombia and Vietnam and the $4^{\text {th }}$ largest partner of Indonesia (Table 1).

Table 1 | Major Trading Partners of CIVETS in 2013 (in \%)

\begin{tabular}{|l|r|l|r|l|c|}
\hline \multicolumn{2}{|c|}{ Colombia } & \multicolumn{2}{c|}{ Indonesia } & \multicolumn{2}{c|}{ Vietnam } \\
\hline United States & 29.7 & China & 14.2 & China & 19.6 \\
\hline European Union & 14.6 & Japan & 12.6 & European Union & 13.2 \\
\hline China & 13.1 & Singapore & 11.4 & United States & 11.4 \\
\hline Mexico & 5.4 & European Union & 8.3 & South Korea & 10.7 \\
\hline Brazil Egypt & 3.5 & South Korea & 6.7 & Japan & 9.9 \\
\hline & 30.7 & European Union & 38.5 & European Union & 25.4 \\
\hline European Union & 7.8 & Russia & 7.9 & China & 14.7 \\
\hline China & 6.7 & China & 7.0 & United States & 7.3 \\
\hline United States & 5.4 & United States & 4.5 & Japan & 5.1 \\
\hline Saudi Arabia & 4.6 & Iran & 3.6 & India & 4.6 \\
\hline Turkey & & & & \\
\hline
\end{tabular}

Note: The five major trading partners of CIVETS have been listed and the amount of trade is presented as a percentage of each country's total trade. Here the European Union is considered to represent euro area as information regarding trade between individual CIVETS countries and the euro area was unavailable.

Source: European Commission Trade Statistics 2013.

The purpose of this research is to investigate, whether CIVETS stock markets are integrated with the European economy as measured by the impact of macroeconomic surprises in the announcements released by the European Monetary Union (EMU) on stock market returns and volatilities. Daily stock market data from CIVETS is analysed for the period from January 1, 2007 to December 31, 2012. Exponential Generalized Autoregressive Conditional Heteroscedasticity (EGARCH) model is one of the commonly preferred and widely used methods to study the impact of macroeconomic announcements on asset prices and the volatility in the markets; it is the method used in this study as well. The starting hypothesis is that stock returns and/or volatilities react, at least to some extent, to the surprises from euro area (EA), because the EA is among the main trading partners and sources of foreign direct investment into CIVETS. However, it is likely that there are differences in the impacts among the CIVETS countries due to the heterogeneity of the CIVETS markets. To the best of the authors' knowledge this is the first study on the surprise effect of the EA macroeconomic news announcements on CIVETS.

The remainder of this paper is organized as follows: The following section presents the theoretical background of studying the effects of macroeconomic announcements. Section 3 provides descriptive statistics for the CIVETS stock markets and descriptions of the EA macroeconomic announcements that are examined in this study. Model specification 
applied to test the surprise effect of the EA macroeconomic announcements is introduced in Section 4. Section 5 presents the results from the study, and Section 6 concludes the paper and provides suggestions for future research.

\section{Background}

The integration between different financial markets has been extensively studied. Many researchers have investigated the integration phenomenon through volatility spillovers among the developed financial markets (e.g. Hamao et al., 1990; Theodossiou and Lee, 1993; Lin et al., 1994; Susmel and Engle, 1994; Karolyi, 1995) and the emerging markets (e.g. Kasch-Haroutounian and Price, 2001; Sola et al., 2002; Li, 2007). Some studies explore integration in terms of volatility and return linkages ( $\mathrm{Li}$ and Majerowska, 2008; Fedorova and Vaihekoski, 2009; Scheicher, 2001), while other studies consider the integration phenomenon between different financial markets (e.g. Yang and Doong, 2004; Francis et al., 2006; Dark et al., 2005; Morales, 2008; Tai, 2007; Yang and Chang, 2008). The integration of financial markets can be analysed by means of macroeconomic news impact. Previous research regarding the effects of macroeconomic news announcements on financial markets is widely studied likewise, but the focus of researchers has mainly been concentrated on the relationships among developed economies.

Macroeconomic announcements provide information on national or regional economic developments for economists and market participants, thus, affecting their decision making and reflecting on the financial markets. The empirical literature distinguishes two sources of news effects (e.g. Rangel, 2011): scheduled macroeconomic announcements that defy observer expectations (the announcement effect) and unexpected macroeconomic announcements (the surprise effect). Surprise announcements are typically more significant for the market than scheduled announcements (e.g. Kim et al., 2004). Some particular financial markets may show interdependence on announcements surprises, while the announcements themselves are not as informative for market participants (Jiang et al., 2010, a study on European markets).

Andersen et al. (2007) examined the interactions among U.S., German, and British stock, bond, and foreign exchange markets with respect to the U.S. macroeconomic news surprises. They found that stock, bond, and exchange rate dynamics are linked to macroeconomic fundamentals. Harju and Hussain (2011) investigated the intraday dynamics of four major European equity markets (France, Germany, Switzerland, and the United Kingdom) with respect to the U.S. macroeconomic news surprises. They found many of the U.S. indicators to have statistically significant influence across these markets. However, mostly macroeconomic surprises seem to have a significant impact only on the conditional volatility, and not on the asset returns.

Nikkinen et al. (2006) studied global stock market integration with respect to surprises of the U.S. macroeconomic news announcements. The results of the research supported the earlier findings (Bekaert and Harvey, 1995; and Rockinger and Urga, 2001) in that market integration seems to be higher among the major stock markets of Europe and Asia with respect to the U.S. macroeconomic news announcements and their surprises, whereas some emerging markets would seem to be more segmented.

Studies that have examined the surprise effect of macroeconomic news announcements on emerging economies have only recently arisen. Hanousek et al. (2009) investigated the impact of the U.S., EU, and neighbouring markets macroeconomic announcements on 
stock returns in three largest emerging EU financial markets (Hungary, the Czech Republic, and Poland). They found that the impact of foreign news is more significant in markets with a larger proportion of foreign investors.

Nowak et al. (2011) investigated how emerging bond markets of Brazil, Mexico, Russia, and Turkey reacted to U.S., German, and local macroeconomic news surprises. The results show that similarly to mature bond markets, both conditional returns and volatility were found to be affected by surprises at the global, regional, and the local macroeconomic levels. This suggests that global and regional news tend to be at least as important, as the local news for emerging bond markets in these countries. However, the absorption of new information was found to be slower in emerging markets, than in the developed markets.

Only few researchers have focussed on studying CIVETS. The rare examples are Korkmaz et al. (2012), studying return and volatility spillovers among (between) CIVETS stock markets, and Yi et al. (2013), comparing CIVETS to BRICs (Brazil, Russia, India, and China) by a scientometric approach. Their findings show interdependence between stock returns and volatilities, and report similarity between these two groups of countries.

The results regarding the impact of macroeconomic news surprises on stock markets vary across regions. Commonly developed markets have been found to respond more to macroeconomic news surprises coming from other markets, and to exhibit a higher level of market integration (e.g. Harju and Hussain, 2011; Andersen et al., 2007; and Bollerslev et al., 2000). Some emerging markets demonstrate increasing integration with the world, with respect to macroeconomic surprises in developed markets (e.g. Hussainey and Ngoc, 2009, or Nguyen, 2011). However, some segmented regions in the world economy will exist (e.g. Turkey and some smaller Asian economies) that exhibit more dependence on the local and the regional news and their surprises, than on global news (Nikkinen et al., 2006; Hanousek et al., 2009; Önder and Simga-Mugan, 2006; and Nowak et al., 2011).

The most common econometric methods used to study the effect of macroeconomic announcements and surprises, as well as integration of financial markets are based on Vector Autoregressive (VAR) analysis (e.g. Lucey and Voronkova, 2006) and Autoregressive Conditional Heteroscedasticity (ARCH) with various extensions (e.g. Hanousek et al., 2009). They can be found in econometric literature (e.g. Brooks, 2005). EGARCH, the method used here, stands out as the most commonly used among the other methods, because the conditional variance in the model remains positive also, when parameters have a negative sign and there is no need for artificial imposition of non-negative constraints of the parameters. Moreover, EGARCH allows asymmetries in volatilities.

\section{Description of the Data}

The stock market data is provided by FactSet. Daily closing prices of MSCI total return indices from January 1, 2007 to December 31, 2012 for Colombia, Indonesia, Vietnam, Egypt, Turkey, South Africa, $r_{t}^{M}$, and the DataStream emerging markets index are used to compute logarithmic return differences, $r_{t}^{E M}$. DataStream emerging markets index is used to control for global emerging market impact on CIVETS. The data period is dictated by availability of stock market data for all CIVETS countries. Historical development of each country stock market from CIVETS group is presented in Figure 1. 


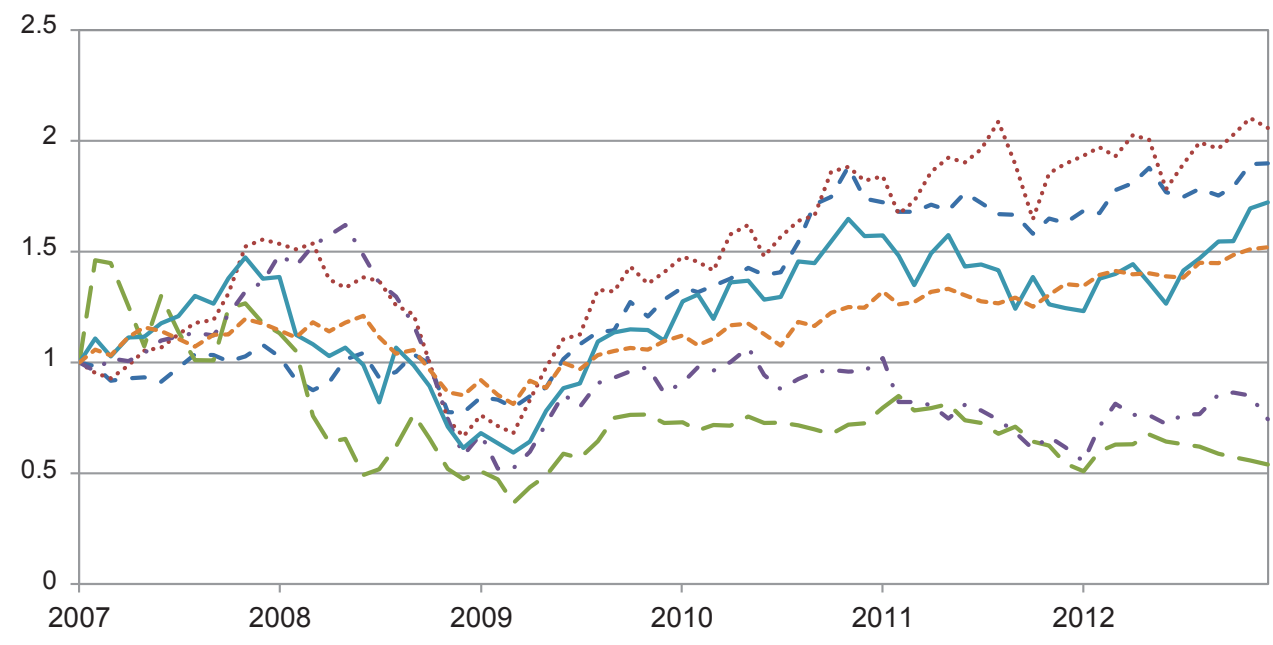

- - - Colombia Indonesia - - Vietnam - - Egypt Turkey $=-\cdots \cdot-$ South Africa

Source: FactSet database. All indices are scaled to 1 in the beginning of 2007.

Figure 2 | Performance of CIVETS, BRIC, Emerging Markets, Europe, and S\&P500 Indices

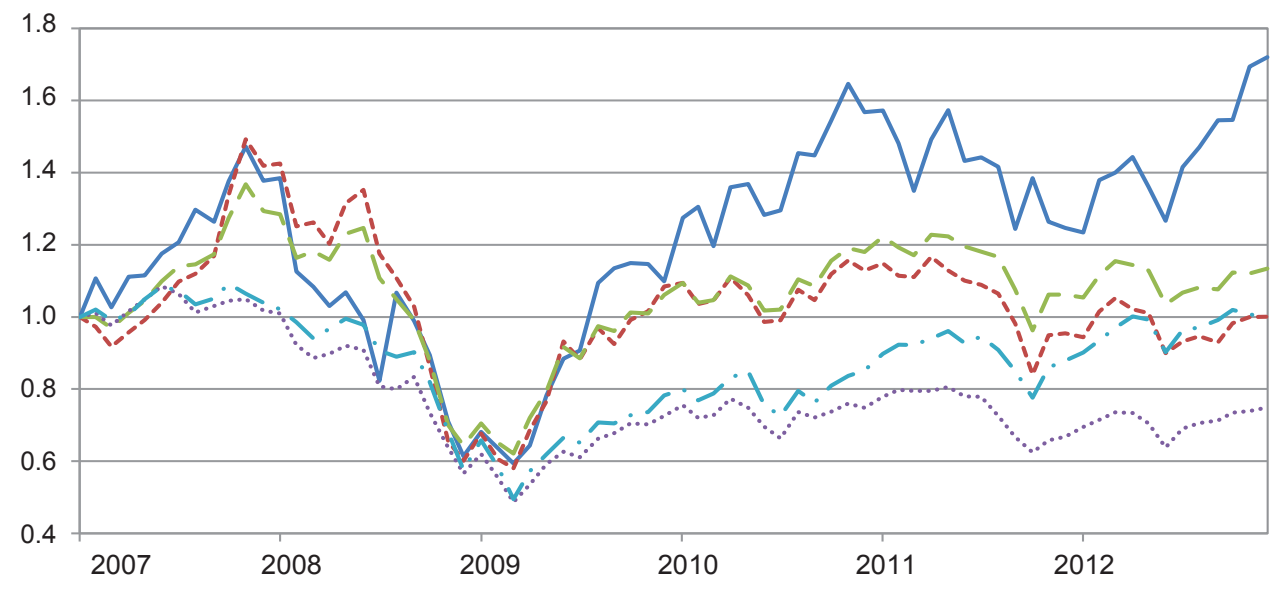

CIVETS -----MSCI BRIC — - MSCI Emerging Europe . MSCI Europe - - S\&P500

Source: FactSet database. All indices are scaled to 1 in the beginning of 2007.

Figure 1 shows that for the whole period of analysis (2007-2012) stock market index of Indonesia has the highest development among all CIVETS followed by Colombia and Turkey, whereas stock market indices of Vietnam and Egypt have lower values at the end of the analysed period than in the beginning of it. Comparing the performance of major developed and emerging stock markets during this period revealed interesting finding that CIVETS had been the most developing markets as aggregate among all other emerging blocks and regional markets whereas Europe had been the least developing of all regions. 
This emphasizes the importance of investigation whether CIVETS markets are affected by macroeconomic surprises coming from Europe. Figure 2 shows the trends of $\$ 1$ invested at the beginning of 2007 until the end of 2012.

Table 2 shows the descriptive statistics for the asset returns for CIVETS countries. Panel A in Table 1 introduces the first four moments. The average returns and standard deviations are annualized. The highest mean return for the period examined is in Indonesia (13.2\%), whereas Vietnam and Egypt experienced negative returns, $-8.2 \%$ and $-2.7 \%$, respectively. The highest standard deviation of asset returns is in Vietnam (31.2\%), while the lowest standard deviation is found in Colombia (19.5\%). The null hypothesis of normal distribution in time series is rejected in all cases (normality results).

\section{Table 2 | Descriptive Statistics for the Asset Returns}

Panel A reports descriptive statistics for the continuously compounded returns of CIVETS and emerging stock markets (as an aggregate). Panel B reports pairwise correlations for the return series. The sample includes 1,510 daily observations for each stock for the period from January 1, 2007 to December 31, 2012. The means and standard deviations in the table have been annualized. The p-values are for the Jarque-Bera test statistic of the null hypothesis of normal distribution.

\begin{tabular}{|c|c|c|c|c|c|c|c|}
\hline \multirow{2}{*}{ Asset return series } & Mean & Std. dev. & \multicolumn{2}{|c|}{ Skewness } & Excess & \multicolumn{2}{|c|}{ Normality } \\
\hline & (\%) & (\%) & & & Kurtosis & \multicolumn{2}{|c|}{ (p-value) } \\
\hline \multicolumn{8}{|l|}{ Panel A: Summary statistics } \\
\hline Colombia & 11.705 & 19.509 & \multicolumn{2}{|c|}{-0.399} & 10.061 & \multicolumn{2}{|c|}{$<0.001$} \\
\hline Indonesia & 13.206 & 29.653 & \multicolumn{2}{|c|}{-0.540} & 9.900 & \multicolumn{2}{|c|}{$<0.001$} \\
\hline Vietnam & -8.193 & 31.217 & \multicolumn{2}{|c|}{0.008} & 4.138 & \multicolumn{2}{|c|}{$<0.001$} \\
\hline Egypt & -2.686 & 29.668 & \multicolumn{2}{|c|}{-1.068} & 12.130 & \multicolumn{2}{|c|}{$<0.001$} \\
\hline Turkey & 10.315 & 30.002 & \multicolumn{2}{|c|}{-0.011} & 9.394 & \multicolumn{2}{|c|}{$<0.001$} \\
\hline South Africa & 7.831 & 21.423 & \multicolumn{2}{|c|}{-0.097} & 5.726 & \multicolumn{2}{|c|}{$<0.001$} \\
\hline Emerging Markets & 2.813 & 20.217 & \multicolumn{2}{|c|}{-0.395} & 10.199 & \multicolumn{2}{|c|}{$<0.001$} \\
\hline Panel B: Pairwise correlations & Colombia & Indonesia & Vietnam & Egypt & Turkey & S. Africa & EM \\
\hline Colombia & 1 & 0.329 & 0.093 & 0.174 & 0.387 & 0.406 & 0.531 \\
\hline Indonesia & & 1 & 0.127 & 0.295 & 0.353 & 0.422 & 0.652 \\
\hline Vietnam & & & 1 & 0.140 & 0.108 & 0.091 & 0.161 \\
\hline Egypt & & & & 1 & 0.191 & 0.210 & 0.312 \\
\hline Turkey & & & & & 1 & 0.527 & 0.593 \\
\hline South Africa & & & & & & 1 & 0.703 \\
\hline Emerging Markets & & & & & & & 1 \\
\hline
\end{tabular}


Panel B in Table 2 reports the pairwise correlations among the examined stock returns. CIVETS stock returns during the observed period have a fairly low cross correlation across the board. The highest correlation among CIVETS is between Turkey and South Africa (0.527). Vietnam has the lowest correlation with the other CIVETS and with the emerging markets aggregate.

Macroeconomic announcements are identified here as scheduled news announcements of macroeconomic indicators from the euro area. Scheduled announcements of eight different macroeconomic indicators $(j)$ are applied in this study. They are: consumer price index (CPI), industrial production (IP), gross domestic product (GDP), retail sales (RS), unemployment (UE), liquidity by M3 (M3), purchasing managers' index (PMI), and consumer confidence (CC).

To test macroeconomic surprise effect on the markets is in other words the difference between the actual effect that markets have taken after a macroeconomic information announcement, and the effect the markets were expected to take. We used mean expectations of the monthly Consensus Economics survey data provided by FactSet as the consensus estimate of each announcement. In this survey a group of economists reveal their expectations about future macroeconomic indicator values. As the expectations are often not in the form of stock market index value, but in the units of the respective macroeconomic indicators, the news surprises are calculated and standardized to facilitate interpretation by using the following approach (for similar way of surprise calculation see Balduzzi et al., 2001, and Hanousek and Kočenda, 2011):

$$
S_{t}^{E A}=\frac{R_{t}-C_{t}}{\sigma},
$$

Where $R_{t}$ and $C_{t}$ are the realization and the consensus estimates of data release at time $t$ and $\sigma$ is the sample standard deviation of the announcement computed from pool of available announcements. This methodology does not affect either the explanatory power of estimates or the regressions since the standard deviation does not change across the observations for particular announcement, while it allows us to compare the significance of regression coefficients across different type of news. Moreover, the data has been fitted so that if MSCI index return was not published on a day of scheduled macroeconomic news announcement or if the announcement is released after the stock market is closed, the impact is studied on the following day. All the data regarding macroeconomic indicators has been retrieved from FactSet.

Table 3 provides information on macroeconomic indicators applied in this study. A similar set of macroeconomic news are used in a similar type of analysis in, e.g. Graham et al., 2003.

Trading hours in CIVETS stock markets vary as measured in GMT. The scheduled macroeconomic announcements have been released prior to the opening of the exchange or during the trading hours for all CIVETS. Thus, the impact of the announcement is examined on the release day. The sample period consist of 1,510 trading days, where 1,065 (70.5\%) trading days had no announcement and $71(4.7 \%)$ trading days had multiple announcements.

The effect of macroeconomic announcement on the financial markets in empirical literature is not always clear (e.g. Hanousek and Kočenda, 2011). For that reason, we define possible impact on the stock markets of CIVETS as hypothetical effects of macroeconomic news surprises. The hypothetical effect on local stock markets is presented in the last column of Table 3, where the expected effect is the outcome when the realized values exceeded the expected values by the market participants. 
Table 3 | Scheduled Macroeconomic News Reports

\begin{tabular}{|l|l|l|l|c|c|c|}
\hline Report & $\begin{array}{l}\text { Abbre- } \\
\text { viation }\end{array}$ & Issued & Issuing office & $\begin{array}{c}\text { Number } \\
\text { of } \\
\text { releases }\end{array}$ & $\begin{array}{c}\text { Release } \\
\text { time } \\
\text { (GMT) }\end{array}$ & $\begin{array}{c}\text { Hypothetical } \\
\text { effect on local } \\
\text { market if } \\
\boldsymbol{R}_{\mathbf{i}, \mathbf{t}}-\mathbf{C}_{i, \mathbf{t}} \mathbf{0}\end{array}$ \\
\hline Consumer price index & CPI & Monthly & Eurostat & 72 & $5.00 \mathrm{AM}$ & Negative \\
\hline Industrial production & IP & Monthly & Eurostat & 72 & $5.00 \mathrm{AM}$ & Positive \\
\hline Gross domestic product & GDP & Quarterly & Eurostat & 24 & $5.00 \mathrm{AM}$ & Positive \\
\hline Retail sales & RS & Monthly & Eurostat & 72 & $5.00 \mathrm{AM}$ & Positive \\
\hline Unemployment & UE & Monthly & Eurostat & 71 & $5.00 \mathrm{AM}$ & Negative \\
\hline M3 & M3 & Monthly & European Central Bank & 71 & $4.00 \mathrm{AM}$ & Positive \\
\hline $\begin{array}{l}\text { Purchasing Managers' } \\
\text { Index }\end{array}$ & PMI & Monthly & Reuters & 71 & $4.00 \mathrm{AM}$ & Positive \\
\hline Consumer confidence & CC & Monthly & $\begin{array}{l}\text { Economic and Financial } \\
\text { Affairs }\end{array}$ & 71 & $5.00 \mathrm{AM}$ & Positive \\
\hline
\end{tabular}

Note: Macroeconomic indicators are collected for the period from 2007 to 2012.

Source: Eurostat, European Central Bank, and FactSet.

In particular, to explain how macroeconomic surprises could affect stock markets in CIVETS, we closely look at the Purchasing Managers' Index. The index value for EA is announced to be 35.60 on $1^{\text {st }}$ of December 2008, whereas the estimated value for the same period is 36.20 . This negative EA macroeconomic surprise result into $-5.65 \%$ stock market return in Turkey only on that particular day. Additionally, a positive surprise in PMI on $3^{\text {rd }}$ of August 2009 (forecasted and realized values are 46.00 and 46.30, respectively) increased Turkish stock market return by $4.47 \%$. The PMI is an indicator of the economic health of the manufacturing sector of the European Monetary Union; thus, its impact could be important in predicting systematic changes in CIVETS stock markets. Therefore, in order to study a systematic impact of EA macroeconomic surprises, this study takes into account macroeconomic surprises in eight different categories.

The computation of news surprises $\left(S_{t}^{E A}\right)$ takes into account categories, which share the same announcement day. Positive surprise for news from such categories as GDP, RS, M3, IP, PMI, and CC has hypothetically positive impact on the market, while positive surprises for UE and CPI are expected to have a negative impact on the financial markets. Thus, the effect from multiple macroeconomic news on the same day $(\lambda)$ is estimated according to the last column on the Table 3 .

\section{Model Specification}

The EGARCH approach, proposed by Nelson (1991), is widely used to study volatility in financial markets (e.g. Koutmos and Booth, 1995). EGARCH $(1,1)$ model with a Gaussian normal distribution of errors is applied in order to examine the effects of EA macroeconomic news surprises on CIVETS stock markets. Thus, the mean (Equation 2 and Equation 4) and the conditional variance (Equation 3 and Equation 5) of baseline EGARCH $(1,1)$ are extended as follows: 
Model 1:

$$
\begin{gathered}
r_{t}^{M}=\mu+\omega r_{t-1}^{E M}+\lambda S_{t}^{E A}+\varepsilon_{t}, \\
\ln \left(\sigma_{t}^{2}\right)=c+\alpha \frac{\left|\varepsilon_{t-1}\right|}{\sigma_{t-1}}+\gamma \frac{\varepsilon_{t-1}}{\sigma_{t-1}}+\beta \ln \left(\sigma_{t-1}^{2}\right)+\sum_{j=1}^{n} \eta_{j} \theta_{j} S_{t}^{E A}, \\
r_{t}^{M}=\mu+\omega r_{t-1}^{E M}+\sum_{j=1}^{n} \eta_{j} \theta_{j} S_{t}^{E A}+\varepsilon_{t}, \\
\ln \left(\sigma_{t}^{2}\right)=c+\alpha \frac{\left|\varepsilon_{t-1}\right|}{\sigma_{t-1}}+\gamma \frac{\varepsilon_{t-1}}{\sigma_{t-1}}+\beta \ln \left(\sigma_{t-1}^{2}\right)+\lambda S_{t}^{E A},
\end{gathered}
$$

Model 2:

where

$M$ denotes individual country,

$E M$ denotes emerging markets index,

$E A$ denotes euro area,

$t$ denotes particular day in analysed period and $t=1, \ldots, T$,

$j \quad$ denotes the $j^{\text {th }}$ news category, all together we have $n=8$ news categories, $\mu, \omega, \lambda, c, \alpha, \gamma, \beta, \eta_{j} \forall j=1, \ldots, n$ are constants.

Also $r_{t}^{M}$ is the daily return for each of CIVETS market $(M)$ at time $t . \sigma_{t}^{2}$ is a conditional variance. $r_{t-1}^{E M}$ represents stock market returns for emerging markets (EM) at time $t-1$. $\omega$ is a parameter representing the lagged effect in returns of EM. $S_{t}^{E A}$ represents the news surprise for macroeconomic announcements at time $t$. Thus, $\lambda$ captures the overall effect of macroeconomic surprises on local stock market. $\theta_{j} \in\{0,1\}$ denotes whether macroeconomic news belongs to news category $j$ or not.

The variance equation in this test is a function of multiple parameters. The parameter $c$ is a constant term, the estimated parameter $\alpha$ represents the symmetric effects of the model. The parameter $\gamma$ indicates asymmetric effects in the model. The parameter $\beta$ measures the persistence of conditional volatility. Parameter $\eta_{j}$ defines the impact of macroeconomic news surprises of particular news category $(j)$ on local stock market.

The presence of asymmetric (leverage) effects in the model can be tested by the hypothesis that parameter $\gamma$ is less than 0 . Positive shocks in the market generate less volatility, than negative shocks, if $\gamma$ is negative. Market volatility is increased more by positive news, than by negative news, if the value of $\gamma$ is positive.

EGARCH with Gaussian normal, t- and generalized error distributions are estimated. No any statistically significant difference among the models is observed. Based on significance of coefficients and explanatory power of the models the Gaussian normal distribution is imposed (following Nelson, 1991).

\section{Empirical Results}

Four preliminary tests (Jarque-Bera, Augmented Dickey-Fuller (ADF), Ljung-Box, and ARCH-LM) are conducted, in order to determine the suitable methodological approach applicable for this study. Jarque-Bera test statistics rejects the null hypothesis of normal distribution in all cases. ADF exhibited no unit root in the data. Ljung-Box test showed that the null hypothesis that the first five autocorrelation coefficients of series are jointly equal to zero is rejected in all markets, except for Turkey evidencing the presence of ARCH in residuals of the estimated models. ARCH-LM test showed the presence of ARCH effect in the stock returns of all CIVETS markets. 
Table 4 | Effects of Macroeconomic News Surprises in Colombia and Indonesia

\begin{tabular}{|c|c|c|c|c|c|c|c|c|}
\hline \multirow{3}{*}{$\begin{array}{l}\text { Parameters } \\
\text { Panel A: Mean equation }\end{array}$} & \multicolumn{4}{|c|}{ Colombia } & \multicolumn{4}{|c|}{ Indonesia } \\
\hline & \multicolumn{2}{|c|}{ Model 1} & \multicolumn{2}{|c|}{ Model 2} & \multicolumn{2}{|c|}{ Model 1} & \multicolumn{2}{|c|}{ Model 2} \\
\hline & Coeff. & SE & Coeff. & SE & Coeff. & SE. & Coeff. & SE. \\
\hline$\mu$ & $0.041^{* *}$ & 0.024 & 0.040 & 0.024 & 0.002 & 0.028 & 0.003 & 0.028 \\
\hline$\omega$ & $0.433^{*}$ & 0.017 & $0.440 *$ & 0.016 & $0.925^{*}$ & 0.019 & $0.924^{*}$ & 0.019 \\
\hline$\lambda$ & 0.050 & 0.046 & - & - & 0.068 & 0.049 & - & - \\
\hline$\eta_{G D P}$ & - & - & 0.117 & 0.352 & - & - & -0.046 & 0.260 \\
\hline$\eta_{R S}$ & - & - & 0.120 & 0.085 & - & - & 0.103 & 0.106 \\
\hline$\eta_{M 3}$ & - & - & -0.164 & 0.100 & - & - & -0.026 & 0.151 \\
\hline$\eta_{I P}$ & - & - & 0.098 & 0.136 & - & - & -0.010 & 0.126 \\
\hline$\eta_{C P I}$ & - & - & -0.043 & 0.122 & - & - & -0.188 & 0.234 \\
\hline$\eta_{U E}$ & - & - & -0.166 & 0.185 & - & - & 0.062 & 0.203 \\
\hline$\eta_{P M I}$ & - & - & -0.069 & 0.117 & - & - & -0.141 & 0.127 \\
\hline$\eta_{\mathrm{cc}}$ & - & - & -0.036 & 0.170 & - & - & 0.221 & 0.190 \\
\hline \multicolumn{9}{|c|}{ Panel B: Volatility equation } \\
\hline c & $-0.244^{*}$ & 0.023 & $-0.246^{*}$ & 0.023 & $-0.204^{*}$ & 0.025 & $-0.204^{*}$ & 0.024 \\
\hline$a$ & $0.305^{*}$ & 0.028 & $0.312^{*}$ & 0.028 & $0.298^{*}$ & 0.033 & $0.295^{*}$ & 0.032 \\
\hline$r$ & $-0.103^{*}$ & 0.017 & $-0.102^{*}$ & 0.017 & $-0.113^{*}$ & 0.020 & $-0.110^{*}$ & 0.019 \\
\hline$\beta$ & $0.854^{*}$ & 0.022 & $0.843^{*}$ & 0.023 & $0.948^{*}$ & 0.010 & $0.951^{*}$ & 0.009 \\
\hline$\lambda$ & - & - & $-0.083^{*}$ & 0.046 & - & - & -0.049 & 0.045 \\
\hline$\eta_{G D P}$ & -0.091 & 0.277 & - & - & -0.060 & 0.120 & - & - \\
\hline$\eta_{R S}$ & -0.083 & 0.082 & - & - & 0.032 & 0.085 & - & - \\
\hline $\boldsymbol{n}_{M 3}$ & -0.032 & 0.100 & - & - & 0.032 & 0.102 & - & - \\
\hline$\eta_{I P}$ & $-0.295^{*}$ & 0.114 & - & - & $-0.193^{*}$ & 0.078 & - & - \\
\hline $\boldsymbol{\eta}_{C P I}$ & 0.078 & 0.182 & - & - & 0.099 & 0.124 & - & - \\
\hline$\eta_{U E}$ & 0.292 & 0.199 & - & - & 0.117 & 0.145 & - & - \\
\hline$\eta_{P M I}$ & $0.239^{*}$ & 0.109 & - & - & -0.064 & 0.092 & - & - \\
\hline$\eta_{\mathrm{cc}}$ & 0.040 & 0.150 & - & - & 0.181 & 0.129 & - & - \\
\hline \multicolumn{9}{|l|}{ Panel C: Diagnostic tests } \\
\hline Adj. $R^{2}$ & & 0.269 & & .273 & & .419 & & 0.420 \\
\hline Log-likelihood & $-2,0 \mathrm{~s}$ & 3.183 & $-2,095$ & .164 & $-2,453$ & .599 & $-2,45$ & 5.073 \\
\hline F-statistic & & 0.609 & & .382 & & 861 & & 78.92 \\
\hline Prob (F-statistic) & & 0.001 & & .001 & & .001 & & 0.001 \\
\hline
\end{tabular}

Source: Authors' calculations. 
Both models (1 and 2) are applied to each of the stock markets. Tables 4-6 report the main results from the EGARCH estimation. Panel A in Tables 4-6 shows the results of the estimated mean equations. The high dependency of CIVETS stock markets on the performance of the EM aggregate is evidenced by positive and statistically significant $\omega$ coefficients. The results in Model 1 suggest that the aggregate impact of macroeconomic surprises have no statistically significant impact on the returns of any CIVETS stock markets (refer to $\lambda$ coefficients).

The results of the estimated mean equation of Model 2 suggest that the individual categories of macroeconomic surprises have different impact on the returns of each CIVETS markets. For example, EA surprises of GDP and unemployment affect stock returns in the Vietnamese market. In contrast to our expectations, a positive surprise $\left(S_{j}^{E A}\right)$ in GDP has a negative impact on returns of Vietnamese and Egyptian markets, which can be attributed to the fact that the EU is seen as one of the biggest consumer markets of Vietnamese and Egyptian products and increase in the real GDP in the EU is taken as a negative sign for local market in Vietnam and Egypt. Additionally, a surprise increase in the unemployment levels in the EU is taken as a negative sign in Vietnam, which is ex-post anticipated since the markets in the EU go into turmoil and can signal a bad future prospective for all trading partners of the EU. Turkish stock returns show a positive impact on the release of higher than expected PMI statistics, which is in line with our earlier expectations (Table 3). In case of South Africa, the local market shows a positive trend on the day of announcements if retail sales (RS) are increased unexpectedly in the EU. This impact is also expected because an increase in sales within the EU reflects a positive impact on the imports from non-EU trading partners as well. No single surprise category affects the stock returns either in Colombia or in Indonesia. This might be explained by the fact that the US is relatively larger trading partner of Colombia than Europe. Similarly, Asian markets including China, Japan, and Singapore are relatively larger trading partners for Colombia and Indonesia than Europe. Hence, EA macroeconomic surprises have been considered as least important by the local market participants.

Panel B in Tables 4-6 illustrates the results of impact of EA macroeconomic surprises on volatility of CIVETS stock markets. Again all of the CIVETS markets exhibit homogeneity in dependence on the own lagged market volatility. This is shown by the positive and significant $\beta$ coefficients, meaning that these volatilities are persistent. Moreover, $\gamma$ coefficients are negative and statistically significant for Colombia, Indonesia, Egypt, and Turkey, suggesting that positive shocks generate less volatility in these markets, than negative shocks, as one would have expected.

In terms of the EA macroeconomic surprises on the CIVETS markets, the aggregate of all macroeconomic surprises generally decrease the volatilities in Colombia, Vietnam, Egypt, and Turkey (see Model 2, coefficient $\lambda$ in Tables 4-6). This suggests that the volatilities of these markets decrease on the day of EA macroeconomic announcements irrespective of the category of the announcement. Indonesia is an exception again since it has relatively lower trade dependency on Europe and, thus, exhibit no reaction to EA macroeconomic surprises in terms of volatility.

Surprisingly, stock market volatility of South Africa does not show significant reaction to the day of announcements. This is not in the line with our expectations as we know that South Africa has close trade ties with Europe and, as a consequence, any macroeconomic surprise (positive or negative) could have impact on the local market. 
Table 5 | Effects of Macroeconomic News Surprises in Vietnam and Egypt

\begin{tabular}{|c|c|c|c|c|c|c|c|c|}
\hline \multirow{3}{*}{$\begin{array}{l}\text { Parameters } \\
\text { Panel A: Mean equation }\end{array}$} & \multicolumn{4}{|c|}{ Vietnam } & \multicolumn{4}{|c|}{ Egypt } \\
\hline & \multicolumn{2}{|c|}{ Model 1} & \multicolumn{2}{|c|}{ Model 2} & \multicolumn{2}{|c|}{ Model 1} & \multicolumn{2}{|c|}{ Model 2} \\
\hline & Coeff. & SE & Coeff. & SE. & Coeff. & SE & Coeff. & SE \\
\hline$\mu$ & $-0.096^{*}$ & 0.039 & $-0.102^{*}$ & 0.040 & -0.033 & 0.045 & -0.017 & 0.046 \\
\hline$\omega$ & $0.213^{*}$ & 0.035 & $0.212^{*}$ & 0.034 & $0.398^{*}$ & 0.028 & $0.424^{*}$ & 0.027 \\
\hline$\lambda$ & 0.028 & 0.077 & - & - & -0.045 & 0.088 & - & - \\
\hline$\eta_{G D P}$ & - & - & $-1.052^{*}$ & 0.278 & - & - & $-0.838^{* *}$ & 0.470 \\
\hline$\eta_{R S}$ & - & - & -0.017 & 0.187 & - & - & -0.118 & 0.263 \\
\hline$n_{M 3}$ & - & - & 0.004 & 0.286 & - & - & -0.25 & 0.235 \\
\hline$\eta_{I P}$ & - & - & 0.158 & 0.168 & - & - & 0.123 & 0.278 \\
\hline$\eta_{C P I}$ & - & - & -0.065 & 0.235 & - & - & -0.148 & 0.259 \\
\hline$n_{U E}$ & - & - & $-0.597^{* *}$ & 0.348 & - & - & 0.324 & 0.256 \\
\hline $\boldsymbol{\eta}_{P M I}$ & - & - & -0.106 & 0.248 & - & - & 0.263 & 0.211 \\
\hline$\eta_{c c}$ & - & - & 0.032 & 0.325 & - & - & 0.062 & 0.282 \\
\hline \multicolumn{9}{|c|}{ Panel B: Volatility equation } \\
\hline c & $-0.131^{*}$ & 0.017 & $-0.145^{*}$ & 0.017 & $0.024^{*}$ & 0.005 & 0.001 & 0.005 \\
\hline$a$ & $0.268^{*}$ & 0.028 & $0.276^{*}$ & 0.028 & -0.004 & 0.005 & $0.036^{*}$ & 0.005 \\
\hline$r$ & -0.023 & 0.016 & -0.025 & 0.016 & $-0.069 *$ & 0.005 & $-0.073^{*}$ & 0.006 \\
\hline$\beta$ & $0.931^{*}$ & 0.012 & $0.935^{*}$ & 0.011 & $0.978^{*}$ & 0.002 & $0.974^{*}$ & 0.003 \\
\hline$\lambda$ & - & - & $-0.087^{*}$ & 0.039 & - & - & $-0.107^{*}$ & 0.016 \\
\hline$\eta_{\text {GDP }}$ & -0.228 & 0.167 & - & - & $-0.204^{*}$ & 0.060 & - & - \\
\hline$\eta_{R S}$ & 0.090 & 0.096 & - & - & 0.029 & 0.031 & - & - \\
\hline $\boldsymbol{\eta}_{M 3}$ & $-0.182^{* *}$ & 0.097 & - & - & $-0.164^{*}$ & 0.036 & - & - \\
\hline$\eta_{1 P}$ & -0.119 & 0.090 & - & - & -0.040 & 0.029 & - & - \\
\hline $\boldsymbol{n}_{C P 1}$ & 0.201 & 0.141 & - & - & $0.082^{*}$ & 0.026 & - & - \\
\hline$\eta_{U E}$ & $0.300^{*}$ & 0.140 & - & - & $0.286^{*}$ & 0.042 & - & - \\
\hline $\boldsymbol{\eta}_{P M I}$ & -0.034 & 0.109 & - & - & $0.067^{*}$ & 0.028 & - & - \\
\hline$\eta_{c c}$ & 0.066 & 0.138 & - & - & $-0.147^{*}$ & 0.041 & - & - \\
\hline \multicolumn{9}{|l|}{ Panel C: Diagnostic tests } \\
\hline Adj. $R^{2}$ & & 0.016 & & 0.017 & & .087 & & 093 \\
\hline Log-likelihood & $-2,98$ & 3.454 & $-2,98$ & 2.783 & $-2,898$ & .877 & $-2,911$ & 085 \\
\hline F-statistic & & 2.700 & & .848 & & .273 & & 041 \\
\hline Prob (F-statistic) & & .001 & & 0.001 & & .001 & $<0$ & 001 \\
\hline
\end{tabular}

Source: Authors' calculations. 
Table 6 | Effects of Macroeconomic News Surprises in Turkey and South Africa

\begin{tabular}{|c|c|c|c|c|c|c|c|c|}
\hline \multirow{3}{*}{$\begin{array}{l}\text { Parameters } \\
\text { Panel A: Mean equation }\end{array}$} & \multicolumn{4}{|c|}{ Turkey } & \multicolumn{4}{|c|}{ South Africa } \\
\hline & \multicolumn{2}{|c|}{ Model 1} & \multicolumn{2}{|c|}{ Model 2} & \multicolumn{2}{|c|}{ Model 1} & \multicolumn{2}{|c|}{ Model 2} \\
\hline & Coeff. & SE & Coeff. & SE & Coeff. & SE & Coeff. & SE \\
\hline$\mu$ & 0.031 & 0.036 & 0.035 & 0.036 & 0.008 & 0.021 & 0.019 & 0.021 \\
\hline$\omega$ & $0.837^{*}$ & 0.026 & $0.847^{*}$ & 0.026 & $0.749^{*}$ & 0.019 & $0.754^{*}$ & 0.018 \\
\hline$\lambda$ & 0.028 & 0.075 & - & - & 0.028 & 0.043 & - & - \\
\hline$\eta_{G D P}$ & - & - & 0.099 & 0.430 & - & - & 0.216 & 0.286 \\
\hline$\eta_{R S}$ & - & - & 0.055 & 0.197 & - & - & $0.171^{* *}$ & 0.103 \\
\hline$\eta_{M 3}$ & - & - & -0.212 & 0.162 & - & - & -0.054 & 0.123 \\
\hline$\eta_{I P}$ & - & - & 0.027 & 0.261 & - & - & 0.146 & 0.102 \\
\hline$n_{C P I}$ & - & - & -0.048 & 0.308 & - & - & 0.196 & 0.152 \\
\hline$\eta_{U E}$ & - & - & 0.257 & 0.233 & - & - & 0.074 & 0.165 \\
\hline$\eta_{P M I}$ & - & - & $0.285^{*}$ & 0.114 & - & - & 0.038 & 0.124 \\
\hline$\eta_{c c}$ & - & - & 0.371 & 0.234 & - & - & -0.177 & 0.161 \\
\hline \multicolumn{9}{|l|}{ Panel B: Volatility equation } \\
\hline c & $-0.061^{*}$ & 0.016 & $-0.072^{*}$ & 0.013 & $-0.120^{*}$ & 0.019 & $-0.127^{*}$ & 0.018 \\
\hline$a$ & $0.137^{*}$ & 0.022 & $0.131^{*}$ & 0.019 & $0.149^{*}$ & 0.023 & $0.155^{*}$ & 0.023 \\
\hline$y$ & $-0.071^{*}$ & 0.016 & $-0.060^{*}$ & 0.015 & -0.019 & 0.019 & -0.003 & 0.018 \\
\hline$\beta$ & $0.944^{*}$ & 0.012 & $0.960^{*}$ & 0.009 & $0.986^{*}$ & 0.005 & $0.987^{*}$ & 0.005 \\
\hline$\lambda$ & - & - & $-0.062^{*}$ & 0.032 & - & - & 0.009 & 0.028 \\
\hline$\eta_{G D P}$ & -0.244 & 0.186 & - & - & 0.213 & 0.130 & - & - \\
\hline$\eta_{R S}$ & 0.111 & 0.085 & - & - & $0.188^{*}$ & 0.077 & - & - \\
\hline$\eta_{M 3}$ & $-0.162^{*}$ & 0.069 & - & - & 0.027 & 0.067 & - & - \\
\hline$n_{I P}$ & 0.003 & 0.069 & - & - & 0.030 & 0.066 & - & - \\
\hline $\boldsymbol{\eta}_{C P I}$ & 0.051 & 0.118 & - & - & -0.016 & 0.084 & - & - \\
\hline$\eta_{U E}$ & 0.058 & 0.091 & - & - & 0.135 & 0.096 & - & - \\
\hline$\eta_{P M I}$ & -0.121 & 0.083 & - & - & 0.029 & 0.094 & - & - \\
\hline$\eta_{c c}$ & $-0.172 * *$ & 0.103 & - & - & 0.148 & 0.095 & - & - \\
\hline \multicolumn{9}{|l|}{ Panel C: Diagnostic tests } \\
\hline Adj. $R^{2}$ & & 0.345 & & .349 & & 0.490 & & 0.492 \\
\hline Log-likelihood & $-2,70$ & 4.401 & $-2,7$ & 04.2 & $-1,92$ & 5.211 & $-1,927$ & 7.563 \\
\hline F-statistic & & 57.714 & & 3.766 & & 4.547 & & 105.3 \\
\hline Prob (F-statistic) & & 0.001 & & .001 & & 0.001 & & 0.001 \\
\hline
\end{tabular}

Source: Authors' calculations. 
The individual impact of each category of macroeconomic surprises on the volatilities of CIVETS markets are shown in Tables 4-6 (Panel B, Model 1). Positive surprises of Money supply indicator (M3) seem to have the most significant impact on CIVETS, decreasing the volatilities of Vietnam, Egypt, and Turkey. Moreover, the volatility of these three markets shows interdependence with European markets. A positive surprise in GDP affects only the Egyptian market, significantly decreasing the volatility. An announcement of unexpected increase in retail sales (RS) in the EU impacts only South African volatility. Positive surprises in industrial production (IP) reduce volatilities in Colombia and Indonesia. An unexpected increase in consumer price index (CPI) affects only Egyptian market volatility, whereas the announcement on unexpected increase in unemployment within the EA increases volatility in Vietnam and Egypt. A positive surprise in consumer confidence (CC) levels in the EA seems to be decreasing volatility in Egypt and Turkey. Lastly, Colombian and Egyptian market volatilities decrease if the purchasing managers' index (PMI) levels increase from the expected levels. These results generally depict the importance of European macroeconomic indicators for all CIVETS markets. However, the impact of macroeconomic announcement on CIVETS cannot be generalized without further investigation of the mechanism of market dependencies. In nutshell, the impact of macroeconomic surprises on local stock market volatilities of CIVETS is according to our expectations with the only exception of PMI.

The results of diagnostic tests are reported in Panel C. The results indicate sufficient explanatory power for measuring the future stock market values in CIVETS countries, with the exception of Vietnam and Egypt. The F-statistic is derived as a test of the hypothesis that the residuals in estimated models are homoscedastic. The p-value for each F-statistic denotes the marginal significance level of each F-test. The models are correctly specified, as the null hypothesis is rejected in the estimated models evidencing the heteroscedasticity of the residuals.

\section{Conclusions and Discussion}

This study aims to examine the linkage of the CIVETS stock markets with the euro area, with respect to scheduled EA macroeconomic news surprises. For this purpose, the impact of scheduled EA macroeconomic surprises on CIVETS stock market returns and volatilities is investigated. The expectation was that stock returns and/or volatilities of CIVETS markets react, to some extent, to the EA macroeconomic surprises, and, thus, indicate interconnectedness between the EA and the CIVETS markets.

The estimated results indicate that EA macroeconomic surprises seem to affect all the CIVETS stock market volatilities and stock returns of four markets. The scope of the impact from macroeconomic surprises on CIVETS markets is heterogeneous. Moreover, information spillovers from the EA to CIVETS are evidenced in all countries. Furthermore, the results revealed that Egyptian market is the most integrated market with the EA, measured by effect of EA macroeconomic surprises, and that Indonesia is the most segmented market among the CIVETS markets. Homogeneity of CIVETS's in dependence of stock market volatilities from their previous values. Negative shocks from macroeconomic surprises were found to have a leverage effect for the most of the CIVETS stock markets; thus, suggesting a negative relationship between market returns and volatility. The impact of different types of macroeconomic news on the volatility is diverse, with respect to each particular country. 
This study supports the perception that CIVETS stock markets react to the EA macroeconomic surprises, suggesting the existence of market integration between the CIVETS markets and the euro area. The evidence of existing spillover effects from EU macroeconomic surprises to the stock markets of CIVETS is consistent with the increased economic and trade relationships between the European Union and CIVETS. Thus, abrupt changes in euro economic area can also be considered as a potential risk factor for portfolio investors in emerging markets, especially CIVETS. These changes need to be taken into account in order to improve risk management strategies.

This research can be extended further by assessing the impact of macroeconomic surprises from other developed economies such as the US and Asia. This study has also highlighted the fact that not only the macroeconomic surprises, but the contents of each category of announcements is important for assessing the true impact of integration between the EU and CIVETS. Therefore, testing the importance of each category of EA macroeconomic indicators on CIVETS markets is an interesting area for future research. Furthermore, local macroeconomic news and their surprises can be used to analyse the relationship between domestic macroeconomic indicators and stock markets of CIVETS in order to understand the local dynamics of these markets.

\section{References}

Andersen, T. G., Bollerslev, T., Diebold, F. X., Vega, C. (2007). Real -Time Price Discovery in Global Stock, Bond and Foreign Exchange Markets. Journal of International Economics, 73(2), 251-277. DOI: 10.1016/j.jinteco.2007.02.004.

Balduzzi, P., Elton, E. J., Green, T. C. (2001). Economic News and Bond Prices: Evidence from the U.S. Treasury Market. The Journal of Financial \& Quantitative Analysis, 36(4), 523-543. DOI: 10.2307/2676223.

Bekaert, G., Harvey, C. R. (1995). Time -Varying World Market Integration. The Journal of Finance, 50(2), 403-444. DOI: 10.1111/j.1540 -6261.1995.tb04790.x.

Bollerslev, T., Cai, J., Song, F. M. (2000). Intraday Periodicity, Long Memory Volatility, and Macroconomic Announcement Effects in the US Treasury Bond Market. Journal of Empirical Finance, 7(1), 37-55. DOI: 10.1016/S0927 -5398(00)00002 -5.

Brooks, C. (2005). Introductory Econometrics for Finance. 6th Ed. Cambridge: The University Press. DOI: 10.1017/CBO9780511841644.

Dark, J., Raghavan, M., Kamepalli, A. (2008). Return and Volatility Spillovers between the Foreign Exchange Market and the Australian All Ordinaries Index. The Journal of Applied Finance, 14(1), 41-48.

Engle, R., Kroner, K. (1995). Multivariate Simultaneous Generalized ARCH. Econometric Theory, 11(1), 122-150. DOI: 10.1017/S0266466600009063.

Fedorova, E., Vaihekoski, M. (2009). Global and Local Sources of Risk in Eastern European Emerging Stock Markets. Czech Journal of Economics and Finance, 59, 2-19.

Francis, B., Hasan, I., Hunter, D. (2006). Dynamic Relations between International Equity and Currency Markets: The Role of Currency Order Flow. Journal of Business, 79, 219-257. DOI: $10.1086 / 497417$.

Graham, M., Nikkinen, J., Sahlström, P. (2003). Relative Importance of Scheduled Macroeconomic News for Stock Market Investors. Journal of Economics \& Finance, 27(2), 153-165. DOI: 10.1007/BF02827216. 
Hamao, Y., Masulis, R., Ng, V. (1990). Correlations in Price Changes and Volatility across International Stock Markets. Review of Financial Studies, 3, 281-307.

DOI: $10.1093 / \mathrm{rfs} / 3.2 .281$.

Hanousek, J., Kočenda, E. (2011). Foreign News and Spillovers in Emerging European Stock Markets. Review of International Economics, 19(1), 170-188.

DOI: 10.1111/j.1467 -9396.2010.00939.x.

Hanousek, J., Koćenda, E., Kutan, A. M. (2009). The Reaction of Asset Prices to Macroeconomic Announcements in New EU Markets: Evidence from Intraday Data. Journal of Financial Stability, 5(2), 199-219. DOI: 10.1016/j.jfs.2008.01.003.

Harju, K., Hussain, S. M. (2011). Intraday Seasonalities and Macroeconomic Announcements. European Financial Management, 17(2), 367-390. DOI: 10.1111/j.1468 -036X.2009.00512.x.

Hussainey, K., Ngoc, L. K. (2009). The Impact of Macroeconomic Indicators on Vietnamese Stock Prices. The Journal of Risk Finance, 10(4), 321-332. DOI: 10.1108/15265940910980632.

Jiang, G., Konstantinidi, E., Skiadopoulos, G. (2012). Volatility Spillovers and the Effect of News Announcements. Journal of Banking \& Finance, 36(8), 2260-2273.

DOI: 10.1016/j.jbankfin.2012.04.006.

Johnson, S. (2008). Emerging Markets Emerge. Finance \& Development - A Quarterly Magazine of the IMF, 45(3), 54-55.

Karolyi, G. (1995). A Multivariate GARCH Model of International Transmissions of Stock Returns and Volatility: The Case of the United States and Canada. Journal of Business and Economic Statistics, 13, 11-25. DOI: 10.1080/07350015.1995.10524575.

Kasch -Haroutounian, M., Price, S. (2001). Volatility in the Transition Markets of Central Europe. Applied Financial Economics, 11, 93-105. DOI: 10.1080/09603100150210309.

Kim, S. -J., Mckenzie, M., Faff, R. (2004). Macroeconomic News Announcements and the Role of Expectations: Evidence for US Bond, Stock and Foreign Exchange Markets. Journal of Multinational Financial Management, 14(4), 217-232. DOI: 10.1016/j.mulfin.2003.02.001.

Korkmaz, T., Cevik, E. I., Atukeren, E. (2012). Return and Volatility Spillovers among CIVETS Stock Markets. Emerging Markets Review, 13(2), 230-252. DOI: 10.1016/j.ememar.2012.03.003.

Koutmos, G., Booth, G. G. (1995). Asymmetric Volatility Transmission in International Stock Markets. Journal of International Money \& Finance, 14(6), 747-762. DOI: 10.1016/0261 $-5606(95) 00031-3$.

Li, H. (2007). International Linkages of the Chinese Stock Exchanges: A Multivariate GARCH Analysis. Applied Financial Economics, 17, 285-297. DOI: 10.1080/09603100600675557.

Li, H., Majerowska, E. (2008). Testing Stock Market Linkages from Poland and Hungary: A Multivariate GARCH Approach. Research in International Business and Finance, 22, 247-266. DOI: 10.1016/j.ribaf.2007.06.001.

Lin, W., Engle, R., Ito, T. (1994). Do Bulls and Bears Move across Borders? International Transmission of Stock Returns and Volatility. Review of Financial Studies, 7, 507-538. DOI: 10.1093/rfs/7.3.507.

Lucey, B., Voronkova, S. (2006). The Relationship between Emerging European and Developed Stock Markets before and after the Russian Crisis of 1997-1998. International Finance Review, 6, 383-413. DOI: 10.1016/S1569-3767(05)06015-2.

Morales, L. (2008). Volatility Spillovers between Equity and Currency Markets: Evidence from Major Latin American Countries. Cuadernos de Economia, 45, 185-215.

Nelson, D. (1991). Conditional Heteroscedasticity in Asset Returns: A New Approach. Econometrica, 59(2), 347-370. DOI: 10.2307/2938260. 
Nguyen, T. (2011). US Macroeconomic News Spillover Effects on Vietnamese Stock Market. The Journal of Risk Finance, 12(5), 389-399. DOI: 10.1108/15265941111176127.

Nikkinen, J., Omran, M., Sahlström, P., Äijö, J. (2006). Global Stock Market Reactions to Scheduled U.S. Macroeconomic News Announcements. Global Finance Journal, 17(1), 92-104. DOI: 10.1016/j.gfj.2006.06.003.

Nofsinger, J. R., Prucyk, B. (2003). Option Volume and Volatility Response to Scheduled Economic News Releases. Journal of Futures Markets, 23(4), 315-345.

DOI: 10.1002/fut.10064.

Nowak, S., Andritzky, J., Jobst, A., Tamirisa, N. (2011). Macroeconomic Fundamentals, Price Discovery, and Volatility Dynamics in Emerging Bond Markets. Journal of Banking \& Finance, 35(10), 2584-2597. DOI: 10.1016/j.jbankfin.2011.02.012.

Önder, Z., Simga -Mugan, C. (2006). How Do Political and Economic News Affect Emerging Markets? - Evidence from Argentina and Turkey. Emerging Markets Finance \& Trade, 42(4), 50-77. DOI: 10.2753/REE1540 -496X420403.

Rangel, J. (2011). Macroeconomic News, Announcements, and Stock Market Jump Intensity Dynamics. Journal of Banking and Finance, 35(5), 1263-1276.

DOI: 10.1016/j.jbankfin.2010.10.009.

Scheicher, M. (2001). The Comovements of Stock Markets in Hungary, Poland and the Czech Republic. International Journal of Finance and Economics, 6, 27-39. DOI: 10.1002/ijfe.141.

Sola, M., Spagnolo, F., Spagnolo, N. (2002). A Test for Volatility Spillovers. Economics Letters, 76, 77-84. DOI: 10.1016/S0165 -1765(02)00027-7.

Susmel, R., Engle, R. (1994). Hourly Volatility Spillovers between International Equity Markets. Journal of International Money and Finance, 13, 3-25. DOI: 10.1016/0261 -5606(94)90021 -3.

Syriopoulos, T. (2006). Risk and Return Implications from Investing in Emerging European Stock Markets. Journal of International Financial Markets, Institutions and Money, 16, 283-299. DOI: 10.1016/j.intfin.2005.02.005.

Tai, C. (2007). Market Integration and Contagion: Evidence from Asian Emerging Stock and Foreign Exchange Markets. Emerging Markets Review, 8, 264-283.

DOI: 10.1016/j.ememar.2006.09.011.

Theodossion, P., Lee, U. (1993). Mean and Volatility Spillovers across Major National Stock Markets: Further Empirical Evidence. Journal of Financial Research, 16, 337-350. DOI: $10.1111 /$ j.1475 -6803.1993.tb00152.x.

Yang, S., Doong, S. (2004). Price and Volatility Spillovers between Stock Prices and Exchange Rates: Empirical Evidence from the G -7 Countries. International Journal of Business and Economics, 3, 139-153.

Yang, Y., Chang, C. (2008). A Double -Threshold GARCH Model of Stock Market and Currency Shocks on Stock Returns. Mathematics and Computers in Simulation, 79, 458-474. DOI: 10.1016/j.matcom.2008.01.048.

Yi, Y., Qi, W., Wu, D. (2013). Are CIVETS the Next BRICs? A Comparative Analysis from Scientometrics Perspective. Scientometrics, 94(2), 615-628.

DOI: $10.1007 / \mathrm{s} 11192-012-0791-9$. 